\title{
Characteristics and Identification of Oxidative Pseudomonads Isolated from Diseased Fish
}

\author{
By G. L. BULLOCK, S. F. SNIESZKO AND C. E. DUNBAR \\ Bureau of Sport Fisheries and Wildlife, Eastern Fish Disease \\ Laboratory, Leetown (P.O. Kearneysville), W.Va., U.S.A.
}

(Received 14 August 1964)

\begin{abstract}
SUMMARY
Several characteristics of 20 strains of oxidative pseudomonads, all but one of which were isolated from freshwater fish, were determined. All strains oxidized glucose and gluconate, produced $\mathrm{NH}_{3}$ from $1 \%$ peptone, grew at $6,12,20$ and $30^{\circ}$ and produced cytochrome oxidase. Lipase was produced by 17 of the strains, while 15 produced gelatinase, and 16 produced fluorescent pigment. These and other characteristics used to identify fishspoilage pseudomonads are also useful for identification of fish-pathogenic pseudomonads. Species determinations from the present data were not attempted. However, from previously published data on speciation of Pseudomonas, most of the 20 strains appeared to be closely related to or identical with $P$. fluorescens.
\end{abstract}

\section{INTRODUCTION}

Pseudomonads, which usually oxidize carbohydrates and produce fluorescent pigment, have been reported as causing diseases in warm-water and cold-water fish (Wolf, 1937 ; Rucker \& Whipple, 1951; Rucker, Earp \& Ordal, 1954; Schäperclaus, 1954; Seaman, 1951). The identification and separation of these organisms from the closely related aeromonads is desirable for diagnosis of the diseases and proper control measures. Current methods used for identification of these pseudomonads lack the precision needed for separation of closely related species or strains isolated from diseased fish. Recent studies on the taxonomy of the genus Pseudomonas have shown the inadequacies of the present classification (Rhodes, 1959; Colwell \& Liston, 1961). Often speciation within the genus has been a matter of personal opinion, or has been based on particular tests considered important by the investigator. This situation is by no means limited to pseudomonads, since one has only to look to the closely related aeromonads to find the same disagreement on speciation (Ewing, Hugh \& Johnson, 1961; Eddy, 1960, 1962). Sneath $(1957 a, b)$ stated that many schemes of taxonomy are catalogues rather than true classifications, and he discussed a computer method for comparing organisms for overall similarity. This method has been applied to several groups of bacteria including those in the genus Pseudomonas (Rhodes, 1961; Colwell \& Liston, 1961; Lysenko, 1961). In our opinion the computer analysis method while having limitations is a sound and objective approach, which promises improvement in bacterial classification. The present work was undertaken for two reasons. First, it was desirable to determine the degree of homogeneity of characteristics of the oxidative pseudo- 
monads isolated from diseased fish, and secondly it was hoped that, by the use of some of their characteristics, better methods of identification of fish-pathogenic pseudomonads could be established.

\section{METHODS}

Selection of cultures. The cultures used in this study (Table 1) were Gram-negative, polarly flagellate rods. With the exception of the two ATCC strains, all cultures came from this laboratory's collection, and all except no. 80 were isolated from fish, most of which were diseased. Culture no. 80 was included because it was isolated from a cold-blooded vertebrate. Characteristics of many of the cultures had been previously studied but not reported. To obtain the characteristics of the strains near the time of isolation, lyophilized cultures were used except in the case of the two ATCC strains and the most recent isolates P-1, P-2, P-3. To ensure purity, all test strains were streaked twice before use.

Table 1. Strains of pseudomonads used

Designation
P. fluorescens
nos. 11250, 12633
$1, \mathbf{2}, \mathbf{3}$
7
11
21
$22 b$
37
49
50,51
66
80
81
$86,87,88$
P-1
P-2, P-3

Original source or source of isolation

American Type Culture Collection

Dr Troutman, Ohio

Quitman, Texas

Brook trout (Salvelinus fontinalis), Berlin, N.H.

Pseudomonas no. 28, Dr R. R. Rucker, State of Washington

Pisgah Forest Hatchery, North Carolina

Adult brook trout ( $S$. fontinalis)

Brook trout fingerling (S. fontinalis), Leetown, West Va.

Pseudomonas Dr R. R. Rucker, State of Washington

Dr Prevost, Canada

Purple salamander (Ambystoma sp.), Leetown, West Va.

Black dace (Rhinichthys atratulus), Leetown, West Va.

Spirit Lake, Iowa

Fathead minnow (Pimephales promelas), Tennessee

Brook trout brood stock (S. fontinalis), Spring Run Trout

Hatchery, Petersburg, West Virginia

Characters examined. Unless otherwise stated, all the following tests were repeated, all media steam sterilized, and all cultures incubated at $20-22^{\circ}$ for 1 week.

1. Cell form and Gram reaction of 18-24 $\mathrm{hr}$ nutrient agar cultures.

2. Flagellation; Novel's (1939) staining method was used.

3. Hydrogen sulphide in Motility Sulfide Medium (Difco; Difco Laboratories, Detroit, Michigan, U.S.A.).

4. Nitrate reduction in nutrient broth containing $0 \cdot 1 \%(\mathrm{w} / \mathrm{v}) \mathrm{KNO}_{3}$; zinc powder (ZoBell, 1932) was used to detect false negatives. Tested after 1, 2, 7 days.

5. MR-VP in MR-VP (Difco) Broth. VP test performed after $48 \mathrm{hr}$ and 1 week.

6. Gelatinase by Smith's modification of Frazier's technique in the Manual of Microbiological Methods (1957).

7. Lecithinase in egg yolk agar; method and medium as in the Manual of Microbiological Methods (1957).

8. Levan production on nutrient agar containing $4 \%(w / v)$ sucrose (Klinge, 1960). A thick slimy growth was considered positive for levan production. 
9. Ammonia production as indicated by increased alkalinity of $1 \%(w / v)$ peptone broth containing $\mathrm{pH}$ indicator.

10. Indole production in $1 \%(\mathrm{w} / \mathrm{v})$ tryptone broth by the method of Kovacs, as in the Manual of Microbiological Methods (1957).

11. Hydrolysis of starch in nutrient agar containing $0 \cdot 2 \%(\mathrm{w} / \mathrm{v})$ soluble starch. Medium flooded with Lugol's iodine solution after incubation.

12. Oxidation of glucose in $\mathrm{O} / \mathrm{F}$ Basal Medium (Difco) containing $1 \%(\mathrm{w} / \mathrm{v})$ glucose. This commercial medium is almost identical with the medium of Hugh \& Leifson (1953).

13. Production of fluorescent pigment was tested on Pseudomonas F Agar (Difco) slopes. This commercial medium is designed to enhance fluorescin production by Pseudomonas. Fluorescence was tested by exposing inoculated slopes to ultraviolet radiation after $24-48 \mathrm{hr}$ incubation. Lyophilized cultures and the same cultures which had been kept for 10 years in stock culture were tested.

14. Growth at different temperatures. All cultures were tested for ability to grow at $0,6,12,20,30,37$ and $42^{\circ}$. The preparation of inocula was a modification of Klinge's (1960) method in that, for each culture tested, a 1/100 dilution, in $0.85 \%$ $(\mathrm{w} / \mathrm{v})$ sterile saline, was made from a $24 \mathrm{hr}$ turbid broth culture. After shaking, $\mathbf{0} \cdot 1 \mathrm{ml}$. of the dilution was inoculated into each tube of nutrient broth, which contained $5 \mathrm{ml}$. broth. Inoculated and control tubes were placed in covered pans of water at the indicated temperatures. Glycerol was added to the pan water at $0^{\circ}$ to keep the water from freezing. Temperatures were checked at least twice a day during the 2-week incubation period and did not fluctuate more than $0 \cdot 5-1 \cdot 0^{\circ}$. It took 30-45 min. from the time the first tubes of a series were inoculated until all tubes of that series had reached proper temperature. Results were recorded daily for the first week and three times during the second week. Growth was measured by visually comparing turbidity of inoculated tubes with uninoculated controls. Tubes were not removed from the incubator for more than $5 \mathrm{~min}$. to record results. Ability to grow at 6, 12, 20 and $30^{\circ}$ was determined once, while ability to grow at 0,37 and $42^{\circ}$ was determined twice.

15. Lipase was demonstrated by: (a) clearing of $1 \%(\mathrm{v} / \mathrm{v})$ tributyrin in nutrient agar; $(b)$ change in colour of $\mathrm{pH}$ indicator in Rhodes (1959) medium substituting peanut oil for olive oil.

16. The presence of cytochrome oxidase was examined by the method of Ewing \& Johnson (1960).

17. The oxidation of gluconate was determined in the medium of Haynes (1951) with the exception that $2 \%(\mathrm{w} / \mathrm{v})$ peptone was substituted for tryptone. The basal medium was autoclaved, and $0.5 \mathrm{ml}$. of a $\mathbf{4 0 . 0} \%(\mathrm{w} / \mathrm{v})$ Seitz-sterilized potassium gluconate solution was added to a final concentration of $4 \%(w / v)$. The inoculated medium was shaken twice by hand during incubation. Presence of reducing compounds was tested with Benedict's qualitative reagent.

\section{RESULTS}

Of the 20 pseudomonads isolated from fish and one salamander, 15 of the strains showed positive reactions for 12 of the 22 applied tests (Fig. 1). Reactions of the strains to the other tests listed in Fig. 1 ranged from 11 to none positive. Detailed 
results of all individual strain reactions are given in Table 2. Flagellar stains indicated most strains were lophotrichous but a few appeared monotrichous. Also the oxidative carbohydrate metabolism of the test strains was confirmed in $\mathbf{O} / \mathbf{F}$ Basal Medium (Difco) containing $1 \%$ glucose. Although the two ATCC strains were similar in their reactions to the test strains, they did differ in lipase production and gluconate oxidation. Also, neither produced gelatinase, which, according to Bergey's Manual (1957), is typical for Pseudomonas fuorescens. It was also found that, when Pseudomonas F Agar (Difco) was used, fluorescence was not lost after repeated subcultivation.

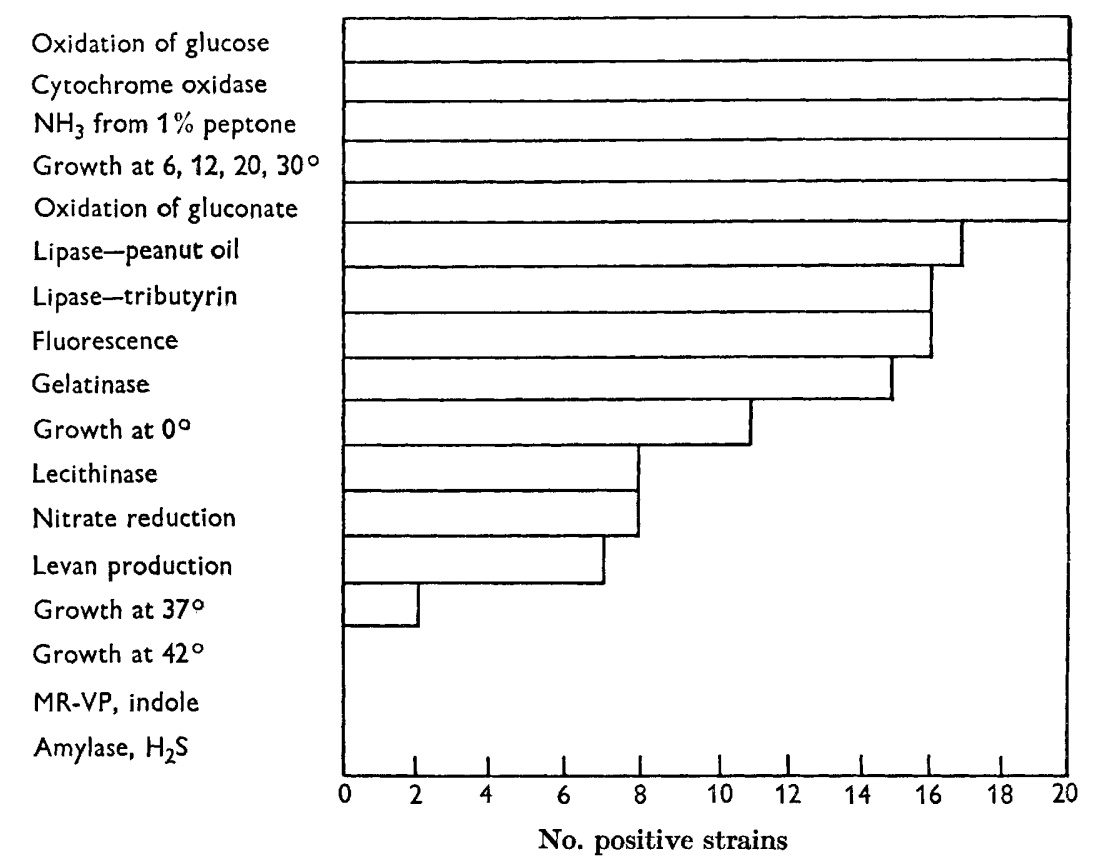

Fig. 1. Number of Pseudomonas strains from fish and one salamander having positive reactions with the applied tests.

\section{DISCUSSION}

The pseudomonads isolated from diseased fish used in the present study represent a fairly homogeneous group, especially in those characteristics normally used for identification, namely polar flagellation, fluorescence, carbohydrate metabolism and cytochrome oxidase reaction. These and other criteria were used by Shewan, Hobbs \& Hodgkiss $(1960 a, b)$ to identify and group the very important pseudomonad spoilage organisms of marine fish. The scheme of Bullock (1961) used to identify fish pathogens also incorporates some of these characteristics for Pseudomonas identification. However, in this scheme a peptone basal medium + carbohydrate was used to determine carbohydrate metabolism and the more definite O/F Basal Medium (Difco) + carbohydrates is now preferred. A further comparison of fish-pathogenic and fish-spoilage pseudomonads would place the pathogens studied into groups I and II of Shewan et al. $(1960 a)$ and, since 16 of the 20 strains 
Table 2. Characteristics of pseudomonad test strains

All strains oxidized glucose, were cytochrome oxidase positive and produced $\mathrm{NH}_{3}$ from $1 \%$ peptone. All strains were MR-VP, amylase, $\mathrm{H}_{2} \mathrm{~S}$, and indole negative.

Culture number (see Table 1)

Character

determined

\begin{tabular}{|c|c|c|c|c|c|}
\hline $\begin{array}{c}1,2 \\
3, \mathbf{P}-2\end{array}$ & 7 & 11 & 21 & $22 b$ & 37 \\
\hline+ & + & + & + & + & + \\
\hline+ & + & + & - & + & + \\
\hline+ & + & - & - & + & + \\
\hline+ & - & + & + & + & + \\
\hline+ & + & + & + & + & + \\
\hline- & - & - & - & - & - \\
\hline- & - & - & - & - & - \\
\hline+ & + & - & + & + & - \\
\hline+ & + & - & - & + & - \\
\hline+ & + & - & - & - & - \\
\hline+ & - & - & - & - & - \\
\hline+ & - & - & - & - & - \\
\hline
\end{tabular}

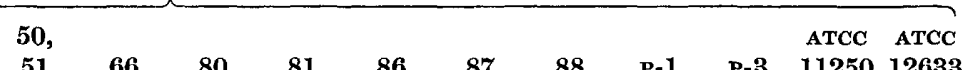

Gluconate oxidation

Lipase

Peanut oil

Tributyrin

Growth at: $0^{\circ}$

\begin{tabular}{l}
$6^{\circ}, 12^{\circ}, 20^{\circ}, 30^{\circ}$ \\
\hline $7^{\circ}$
\end{tabular}

37

Fluorescence

Gelatinase

Lecithinase

Levan

Nitrate reduction

8081

$86 \quad 87$

$+\quad+$

$+\quad+$

$++$

$+$

$\begin{array}{ll}+ & + \\ + & + \\ + & + \\ + & + \\ - & - \\ - & - \\ + & + \\ + & + \\ - & + \\ - & - \\ + & -\end{array}$

$\begin{array}{ll}+ & + \\ + & + \\ + & + \\ + & + \\ - & + \\ - & + \\ + & + \\ + & + \\ - & + \\ - & \end{array}$


produced fluorescent pigment, mainly in group I. Organisms producing an alkaline or no reaction in the medium of Hugh \& Leifson (1953) and corresponding to groups III and IV (Shewan et al. 1960 a) are rarely encountered as pathogens of fish and are of no practical importance in this field.

While speciation was not an aim of this work it may be possible on the basis of growth at various temperatures more closely to define our strains. The ability to grow at $42^{\circ}$ is considered an important feature in the separation of $\boldsymbol{P}$ seudomonas aeruginosa from other Pseudomonas species (Haynes, 1951; Klinge, 1960; Haynes \& Rhodes, 1962). Haynes \& Rhodes (1962) recommended three successive transfers for determining growth at $42^{\circ}$. This was not used in the present work, but since after two attempts no strain was found to grow at $42^{\circ}$ and only two strains grew at $37^{\circ}$, it is unlikely that $\boldsymbol{P}$. aeruginosa plays an important role in diseases of freshwater fish. We are mainly concerned with psychrophilic pseudomonads, which are identical with or closely resemble $\boldsymbol{P}$. fluorescens.

The authors wish to thank Dr K. E. Wolf of this laboratory for his critical review of the manuscript and many helpful suggestions.

\section{REFERENCES}

Bergey's Manual of Determinative Bacteriology (1957). 7th ed. Ed. by R. S. Breed, E. G. D. Murrey \& N. R. Smith. Baltimore, U.S.A.: Williams and Wilkins Co.

Bullock, G. L. (1961). A schematic outline for the presumptive identification of bacterial diseases of fish. Progr. Fish. Cult. 23, 147.

Colwell, R. R. \& Liston, J. (1961). Taxonomic relationships among the pseudomonads. J. Bact. 82, 1.

EDDy, B. P. (1960). Cephalotrichous, fermentative Gram-negative bacteria: the genus Aeromonas. J. appl. Bact. 23, 216.

Eddy, B. P. (1962). Further studies on Aeromonas. I. Additional strains and supplementary biochemical tests. J. appl. Bact. 25, 137.

Ewing, W. H. \& Johnson, J. G. (1960). The differentiation of Aeromonas and C27 cultures from Enterobacteriaceae. Int. Bull. bact. Nomencl. 10, 223.

Ewing, W. H., Hugh, R. \& Johnson, J. G. (1961). Studies on the Aeromonas group. U.S. Dep. of Health, Education and Welfare, Public Health Service, Communicable Disease Center, Atlanta, Georgia, $37 \mathrm{pp}$.

Haynes, W. C. (1951). Pseudomonas aeruginosa-its characterization and identification. J. gen. Microbiol. 5, 939.

Haynes, W. C. \& Rhodes, L. J. (1962). Comparative taxonomy of crystallogenic strains of Pseudomonas aeruginosa and Pseudomonas chlororaphis. J. Bact. 84, 1080.

Hugh, R. \& Leifson, E. (1953). The taxonomic significance of fermentative versus oxidative metabolism of carbohydrates by various Gram negative bacteria. J. Bact. 66, 24.

KuINGe, K. (1960). Differential techniques and methods of isolation of Pseudomonas. J. appl. Bact. $23,442$.

Lysenko, O. (1961). Pseudomonas-an attempt at a general classification. J. gen. Microbiol. 25, 379.

Manual of Microbiological Methods (1957). Ed. Committee on Bacteriological Technic, Society of American Bacteriologists. New York: McGraw-Hill.

Novel, E. (1939). Une technique facile et rapide mise en évidence des cils bactériens. Ann. Inst. Pasteur, Paris, 63, 302.

Rhodes, M. E. (1959). The characterization of Pseudomonas fluorescens. J. gen. Microbiol. 21, 221. 
Rhodes, M. E. (1961). The characterization of Pseudomonas fluorescens with the aid of an electronic computer. J. gen. Microbiol. 25, 331.

Rucker, R. R., Earp, B. J. \& Ordal, E. J. (1954). Infectious diseases of Pacific salmon. Symposium on Fish Diseases. Trans. Amer. Fish. Soc. 83, 297.

Rucker, R. R. \& Whipple, W. J. (1951). Effect of bacteriocides on steelhead trout fry. Progr. Fish. Cult. 13, 43.

SchäPERClaus, W. (1954). Fischkrankheiten. Berlin: Akademie-Verlag.

Seaman, W. R. (1951). Notes on a bacterial disease of rainbow trout in a Colorado hatchery. Progr. Fish. Cult. 13, 139.

Shewan, J. M., Нobrs, G. \& Hodgkiss, W. (1960a). A determinative scheme for the identification of certain genera of Gram-negative bacteria, with special reference to the Pseudomonadaceae. J. appl. Bact. 23, 379.

Shewan, J. M., Hobbs, G. \& Hodgkiss, W. (1960 b). The Pseudomonas and Achromobacter groups of bacteria in the spoilage of marine white fish. J. appl. Bact. 23, 463.

SNeath, P. H. A. (1957a). Some thoughts on bacterial classification. J. gen. Microbiol. $17,184$.

SNEATH, P. H. A. (1957b). The application of computers to taxonomy. J. gen. Microbiol. 17, 201.

WolF, L. E. (1937). An air bladder disease in lake trout fingerlings. Trans. Amer. Fish. Soc. 66, 359.

ZoBeLL, C. E. (1932). Factors influencing the reduction of nitrate and nitrites by bacteria in semi-solid media. J. Bact. $24,273$. 
